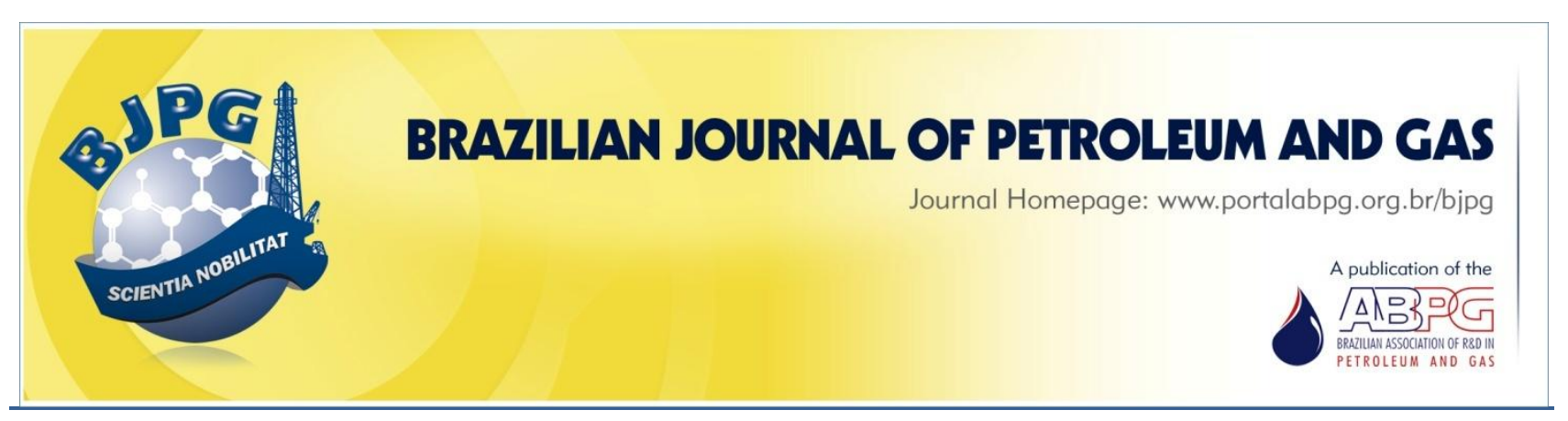

\title{
THE EVALUATION OF THE IMPORTANCE OF ADDITIVES IN COOLING TOWER OPERATIONS
}

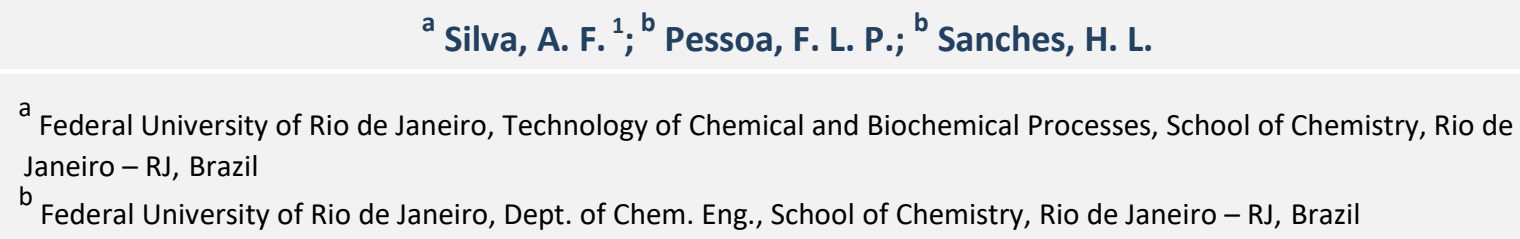

\begin{abstract}
Cooling water production is very important to oil refineries, and cooling towers are associated with high costs. An analysis of blowdown and make-up streams, cycles of concentration, use of biocides, and corrosion and scale inhibitors, can be performed to find alternatives to reduce process costs. Furthermore, a cooling system with chemical additives is advantageous because it prolongs the lifespan of the cooling tower. It also permits the elevation of the concentration cycle, consequently, reducing the cost of makeup water and minimizing inhibitors. This work seeks the optimization of cooling tower in terms of make-up water and suggests the use of chemical additives for reducing costs. The optimization was performed for scenarios with different make-up water compositions, and the Puckorius Scaling Index (PI) was evaluated to assure the quality of the water. The results showed that the lowest cost is obtained with the highest allowed cycle of concentration, according to the Puckorius Scaling Index interval.
\end{abstract}

\section{KEYWORDS}

cooling tower; optimization; cost

\footnotetext{
${ }^{1}$ To whom all correspondence should be addressed. Address: Escola de Química/UFRJ, Av. Athos da Silveira Ramos 149, Centro de Tecnologia, Bloco E, sala E-207, Ilha do Fundão, Rio de Janeiro - RJ, Brasil. ZIP Code: 21941-909 | Telephone: +55 21 3938-7603 |e-mail: amandafernandes@ufri.br doi:10.5419/bjpg2017-0001
} 


\section{INTRODUCTION}

The main use of the water in oil refineries is for cooling the processes or equipment by reducing or removing the heat from them. The water is normally used as a cooling fluid, because it has high specific heat, low viscosity, high thermal conductivity, and high density (Omni, 1989).

Because of the increasing scarcity of water resources and the capacity of the oil refineries, the adoption of measures that ration the use of water is important, such as the reuse of industrial wastewater. Thus, wastewater reuse in the cooling tower and the optimization of the operational conditions are essential for reaching an attractive cost-benefit relationship.

Some important parameters in the operation of a cooling tower are the heat load (the amount of heat transferred from the water to the air stream), the recirculating water flow rate, the range (the difference between inlet and outlet temperatures of the water in the tower), and the approach (the difference between the outlet water temperature and the wet-bulb temperature of the air).

Some studies in the literature relate the cooling tower optimization, such as Castro et al. (2000), Kim et al. (2001), Cortinovis et al. (2009), SernaGonzález et al. (2010), and Souza (2010).

Castro et al. (2000) developed an operational cost minimization model for a cooling water system that supplies a heat exchanger network. In this work, the model includes the energy cost and the make-up water cost, and nonlinear programming is used to solve it. The results showed that the forced removal of a part of the water that enters the tower with the make-up water is an optimal solution for situations that require additional heat removal. Case studies showed that the wet-bulb temperature is the variable that most influences the tower performance.

Kim et al. (2001) optimized a cooling tower, determining the minimum total cost of the cooling system. From the capital cost (a function of the circulating water flow, range, approach, and the wet-bulb temperature) and the operational cost (the power consumed by the fan and the pump), the optimal conditions were achieved. This work proposes that the total optimal cost may not always be obtained with the minimum water flow.
Cortinovis et al. (2009) developed an operational cost minimization model for a system composed of a crossflow cooling tower and a network of heat exchangers, using nonlinear programming. The objective function is given by the cost of electricity consumed by the pumps and fans, and the make-up water cost. From the case studies, the most important variables to reduce the operational costs are circulating water flow rate, air flow rate, and flow rate of the forced removal of a part of the water that enters the tower with the make-up water.

The work of Serna-González et al. (2010), a model shows a formula to minimize the total annual cost of a counter flow cooling tower, using the mixed-integer nonlinear programming. In this study, an objective function includes the capital and operational costs. The obtained results showed that operational costs are proportional to the range, while capital costs depend on the optimal relation between range and air flow. Besides, the cooling tower packing area was considered an important variable for influencing the total annual cost.

Souza (2010) used linear-programming to minimize the cooling tower operational cost, including water, cost of effluent treatment, and cost of water treatment. Because of the high cost of the water treatment, the optimal operational cost was obtained for the minimum blowdown flow and, consequently, the maximum cycle of concentration.

Then, the entire work analyzed the operational cost of the cooling tower. However, they did not consider the cost of additives, which are important for avoiding the formation of deposits, fouling, corrosion and biodeposits, and for prolonging the cooling tower lifespan.

Therefore, this work consists of the cooling tower optimization in terms of make-up water and the reduction of chemical additives costs. The optimization was performed for scenarios with different make-up water compositions, and the Puckorius Scaling Index (IP) was evaluated to assure the quality of the water. 


\section{METHODOLOGY}

\subsection{Cooling tower equations}

The cooling system studied in this work is shown in Figure 1, which represents an open recirculating cooling tower.

In cooling systems, the make-up water is used to replace the losses caused by evaporation, drift, blowdown, and possible leaks (Femp, 2011). Equation 1 represents the make-up flow rate $\left(\dot{Q}_{m}\right)$ :

$\dot{Q}_{m}=\dot{Q}_{b}+\dot{Q}_{e}+\dot{Q}_{d}+\dot{Q}_{l}$

where $\dot{Q}_{b}$ is the blowdown water flow rate, $\dot{Q}_{e}$ is the water flow rate lost by evaporation, $\dot{Q}_{d}$ is the water flow rate lost by drift, and $\dot{Q}_{l}$ is the water flow rate lost by possible leaks.

Considering that the salt concentration in the water lost by evaporation is equal to zero and that the salt concentration in the streams of blowdown, drift and leaks is equal to cs; the make-up water flow rate is expressed by Equation 2. The cycle of concentration (CC) is represented by Equation 3 (Perry, 2008). The higher the concentration of the dissolved salts, the greater the number of cycles of concentration and the need for use of scale and corrosion inhibitors are:

$\dot{Q}_{m} \cdot c_{m}=c_{s} \cdot\left(\dot{Q}_{b}+\dot{Q}_{d}+\dot{Q}_{l}\right)$

$C C=\frac{c_{s}}{c_{m}}$

where $c_{m}$ is the salt concentration in the make-up water, and $c_{S}$ is the salt concentration in the recirculating water.

In the cooling tower, the amount of latent heat of vaporization can be equal to the sensible heat lost by the water droplets of the stream that was not evaporated, as shown in Equation 4 (Pereira, 2001):

$\dot{Q}_{e} \cdot \lambda=\left(\dot{Q}_{w}-\dot{Q}_{e}\right) \cdot c_{p w} \cdot\left(T_{w 1}-T_{w 2}\right)$

where $c_{p w}$ is the water specific heat, $T_{w 1}$ is the inlet water temperature, $T_{w 2}$ is the outlet water temperature, $\lambda$ is the water latent heat of evaporation, $\left(\dot{Q}_{w}-\dot{Q}_{e}\right)$ is the flow rate of the stream that was not evaporated, and $\dot{Q}_{w}$ is the recirculating water flow rate.

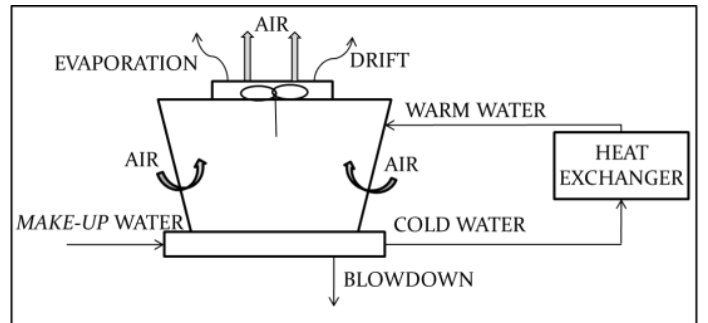

Figure 1. Illustration of an open recirculating cooling system.

Considering that $c_{p w}=4.18 \mathrm{~kJ} /\left(\mathrm{kg} \cdot{ }^{\circ} \mathrm{C}\right)$ at $25^{\circ} \mathrm{C}, \lambda=2.42 \cdot 10^{3} \mathrm{~kJ} / \mathrm{kg}$ at $25^{\circ} \mathrm{C}$, and $5^{\circ} \mathrm{C}<$ $\left(T_{w 1}-T_{w 2}\right)<20^{\circ} \mathrm{C}$, the water flow rate lost by evaporation can be simplified to Equation 5 (Pereira, 2001). It gives an approximate value of the evaporation stream in the open recirculating cooling tower in tropical countries (Veiga, 2010).

$\dot{Q}_{e}=0.00173 \cdot \dot{Q}_{w} \cdot\left(T_{w 1}-T_{w 2}\right)$

The drift can be estimated by Equation 6 (Perry, 2008):

$\dot{Q}_{d}=0.001 \dot{Q}_{w}$

The maximum cycle of concentration can be determined according to the contaminants concentration in the cooling water, like calcium carbonate, calcium sulfate, and silica. For example, the maximum silica concentration in the recirculating water must be $180 \mathrm{ppm}$. Then, the maximum cycle of concentration $\left(C C_{\max }\right)$ according to silica levels is represented in Equation 7 (Pereira, 2001):

$C C_{\max }=\frac{180}{\left(c_{\mathrm{SiO}_{2} \mathrm{~m}}\right)}$

where $c_{\mathrm{SiO}_{2} \mathrm{~m}}$ is the silica concentration in the make-up water.

The inhibitors dosages depend on many factors, like the operating characteristics of the cooling system and the quality of the cooling water. Some examples of initial and maintenance dosages of corrosion inhibitors are shown in Table 1 (Basham et al., 2005).

Equation 8 calculates the slug dose of chemical additives $\left(D_{a}\right)$ used to establish an initial dosage of the corrosion inhibitors to form a passivation film (Pereira, 2001). The initial concentration of the 
Table 1. Initial and maintenance dosages of corrosion inhibitors in cooling systems.

\begin{tabular}{cccc}
\hline $\begin{array}{c}\text { Corrosion } \\
\text { inhibitor/active } \\
\text { ingredient }\end{array}$ & $\begin{array}{c}\text { Initial dosage } \\
(\mathbf{m g} / \mathrm{L})\end{array}$ & $\begin{array}{c}\text { Maintenance } \\
\text { dosage }(\mathrm{mg} / \mathrm{L})\end{array}$ & $\begin{array}{c}\text { Film } \\
\text { formation } \\
\text { time (days) }\end{array}$ \\
\hline $\begin{array}{c}\text { Anodic Inhibitor } \\
\text { (phosphate) }\end{array}$ & $40-60$ as PO $^{-3}$ & $15-20$ as $\mathrm{PO}_{4}^{-3}$ & $5-6$ \\
$\begin{array}{c}\text { Cathodic Inhibitor (zinc) } \\
\text { Copper corrosion } \\
\text { inhibitor (tolyltriazole) }\end{array}$ & $10-20$ as $\mathrm{Zn}^{+2}$ & $3-5$ as $\mathrm{Zn}^{+2}$ & $5-6$ \\
\hline
\end{tabular}

chemical additive is approximately 2-3 times its maintenance level (Cheremisinoff \& Cheremisinoff, 1981).

$D_{a}=\frac{c_{a 0} \cdot V}{1000}$

where $c_{a 0}$ is the initial concentration of the chemical additive in the recirculating water, and $\mathrm{V}$ is the volume of water in the cooling system.

Equation 9 estimates the continuous dose of chemical additives $\left(\dot{m}_{a}\right)$ used to maintain the concentration of cooling water inhibitors to prevent corrosion and deposition (Cheremisinoff \& Cheremisinoff, 1981):

$\dot{m}_{a}=\frac{c_{a} \cdot \dot{Q}_{m}}{(C C \cdot 1000)}$

where $c_{a}$ is the maintenance concentration of the chemical additive in the recirculating water.

Furthermore, chlorine is a biocide used largely in cooling water systems. The free chlorine residual concentration consists of the amount of chlorine that is available for biocidal action after adding the dose and meeting the system demands (Rajagopal et al., 2012). The free chlorine residual concentration in open recirculating systems is generally about $0.1-0.5 \mathrm{mg} / \mathrm{L}$ (GE, 2017). Equation 10 estimates the dosage of chlorine solution $\left(\dot{m}_{\text {sol }}\right)$, such as sodium hypochlorite solution (Cheremisinoff \& Cheremisinoff, 1981):

$\dot{m}_{s o l}=\frac{c_{c l} \cdot \dot{Q}_{w}}{\% p / p \cdot 1000}$

where $c_{c l}$ is the concentration of chlorine in the recirculating water and $\% p / p$ is the weight percent of active chlorine in the solution.

The Puckorius Scaling Index (PI) of the water is used to assess the calcium carbonate scale potential in the cooling system. Equation 11 represents such index (Gentil, 2003):

$P I=\left(2 \cdot p H_{s}\right)-p H_{e q}$

where $p H_{s}$ is the saturation $\mathrm{pH}$, and $p H_{e q}$ is the equilibrium $\mathrm{pH}$.

The saturation $\mathrm{pH}$ is calculated by Equation 12, composed by the coefficients $A, B, C$, and $D$; which can be calculated by Equations 13, 14, 15, and 16, respectively (Roberge, 2007):

$p H_{s}=(9.3+A+B)-(C+D)$

$A=\frac{\log \left(c_{T D S c}\right)-1}{10}$

$B=-13.12 \cdot \log \left(T_{m}+273\right)+34.55$

$C=\log \left(c_{C a^{2+}}\right)-0.4$

$D=\log \left(c_{A T c}\right)$

where $c_{T D S} c$ is the total dissolved solids in the recirculating water, $T_{m}$ is the make-up water

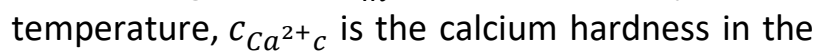
recirculating water, and $c_{A T} c$ is the total alkalinity in the recirculating water.

Equation 17 calculates the equilibrium $\mathrm{pH}$ $\left(p H_{e q}\right)$ :

$p H_{e q}=1.47 \cdot \log \left(c_{A T c}\right)+4.54$ 
The cooling water scaling conditions according to the $\mathrm{PI}$ is presented in Table 2 (Carrier, 1965 apud Mirre, 2012).

\subsection{Cooling tower costs}

The total cost of the cooling tower includes the capital cost and the operational cost, as shown in Equation 18 (Serna-González et al., 2010):

$C_{\text {TOT }}=C A P E X \cdot F+O P E X$

where $\mathrm{F}$ is the annualized factor of capital cost, CAPEX is the capital cost, and OPEX is the operational cost.

The capital cost based on the tower fill volume is shown in Equation 19 (Serna-González et al., 2010):

$$
C A P E X=C_{C T V} \cdot A_{f r} \cdot Z
$$

Where $C_{C T V}$ is the cooling tower cost based on fill volume, $A_{f r}$ is the cross-sectional area of the cooling tower, and $Z$ is the fill height.

The operational cost, which is shown in Equation 20, was based on the make-up water, the electricity consumed by the fan and the pump, and the use of chemical additives.

$$
\begin{aligned}
& \text { OPEX }=H_{Y} \cdot C_{c m} \cdot \dot{Q}_{m}+ \\
& +H_{Y} \cdot C_{c e} \cdot\left(P O W_{p}+P O W_{f}\right)+ \\
& +H_{Y} \cdot\left(\dot{m}_{s o l} \cdot C_{c s}\right)+\sum_{n}^{N T} D_{a, n} \cdot C_{c a, n}+ \\
& +\sum_{n}^{N T} H_{Y} \cdot\left(C_{c a, n} \cdot \dot{m}_{a, n}\right)
\end{aligned}
$$

Where $H_{Y}$ is the yearly operating time, $C_{c m}$ is the make-up water cost coefficient, $C_{c e}$ is the electricity cost coefficient, $P O W_{p}$ is the pump power, $P O W_{f}$ is the fan power, $C_{c s}$ is the cost coefficient of chlorine solution (sodium hypochlorite), $D_{a, n}$ is the slug dosage of the chemical additive $\mathrm{n}, C_{c a, n}$ is the cost coefficient of the chemical additive $\mathrm{n}, \dot{m}_{a, n}$ is the continuous dosage of the chemical additive $\mathrm{n}$, and NT is the total number of chemical additives except the biocide (chlorine).
Table 2. The cooling water scaling conditions according to the PI.

\begin{tabular}{cc}
\hline $\begin{array}{c}\text { Puckorius Index } \\
(\mathrm{PI})\end{array}$ & $\begin{array}{c}\text { Characteristic of the cooling } \\
\text { water }\end{array}$ \\
\hline $\mathbf{4}<\mathrm{PI} \leq 5$ & Strong scale formation \\
$\mathbf{5}<\mathrm{PI} \leq 6$ & Slight scale formation \\
$\mathbf{6}<\mathrm{PI} \leq 7$ & Little corrosion or scale \\
& formation (stable) \\
$\mathbf{7}<\mathrm{PI} \leq 7.5$ & Significant corrosion \\
$7.5<\mathrm{PI} \leq 9$ & Strong corrosion \\
$\mathbf{P I}>\mathbf{9}$ & Very strong corrosion \\
& (intolerable) \\
\hline
\end{tabular}

\subsection{Case study}

This work consists of an analysis of how to achieve the minimization of the make-up water and a reduction in costs of chemical additives used in the cooling tower of the Coking Unit of the Gabriel Passos Refinery (REGAP), located in Betim, MG - Brazil. The cooling system was optimized for different make-up water scenarios, and the Puckorius Scaling Index (PI) was evaluated to assure the quality of the water.

\subsubsection{Make-up water scenarios}

The make-up water scenarios studied in this work are presented in Table 3. The make-up water scenarios $M 1, M 2, M 3$, and $M 4$ correspond to the possible options for the cooling tower of REGAP studied by Veiga (2010). The scenario M5 represents the groundwater of the São Domingos River Basin, located in Rio de Janeiro, Brazil (Santos, 2009). Scenario M6 represents the water quality standards for the make-up water of the cooling tower of the Galeão, Rio de Janeiro's International Airport (Carvalho \& Machado, 2010).

\subsubsection{Chemical additives}

The chemical additives used in the cooling tower of REGAP studied by Veiga (2010) are reported in Table 4. The initial recommended doses of polyacrylate, phosphate, zinc, and azole were 20 $\mathrm{mg} / \mathrm{L}, 50 \mathrm{mg} / \mathrm{L}, 15 \mathrm{mg} / \mathrm{L}$, and $15 \mathrm{mg} / \mathrm{L}$, respectively. 
Table 3. Make-up water scenarios.

\begin{tabular}{|c|c|c|c|c|c|c|}
\hline Parameter & M1 & M2 & M3 & M4 & M5 & M6 \\
\hline Temperature (K) & 313 & 313 & 313 & 313 & 301.7 & 297.9 \\
\hline Total dissolved solids (mg/L) & 272 & 340 & 633.08 & 876.75 & 237 & 500 \\
\hline Total alkalinity $\left(\mathrm{mg} \mathrm{CaCO}_{3} / \mathrm{L}\right)$ & 50 & 22 & 30 & 30 & 188 & 29 \\
\hline Chloride (mg Cl/L) & 50 & 68 & 100 & 60 & 20.16 & 29 \\
\hline pH & 6.9 & 6.9 & 7.0 & 6.9 & 7.08 & 7 \\
\hline Calcium hardness $\left(\mathrm{mg} \mathrm{CaCO}_{3} / \mathrm{L}\right.$ ) & 46 & 80 & 28 & 19 & 13.75 & 125 \\
\hline Silica (mg SiO $2 / \mathrm{L})$ & 6.0 & 7.4 & - & - & 21.9 & 21 \\
\hline
\end{tabular}

Table 4. Chemical additives used in the cooling tower.

\begin{tabular}{lccc}
\hline \multicolumn{1}{c}{$\begin{array}{c}\text { Chemical Additive/ Active } \\
\text { ingredient }\end{array}$} & $\begin{array}{c}\text { Product/ Concentration of } \\
\text { active ingredient }\end{array}$ & $\begin{array}{c}\text { Price } \\
\text { (R\$/kg) }\end{array}$ & $\begin{array}{c}\text { Residual concentration of } \\
\text { active ingredient in the } \\
\text { recirculating water (mg/L) }\end{array}$ \\
\hline Dispersant (polyacrylate) & DISPERSOLTC5H $\left(40 \%^{*}\right)$ & $14.156^{* *}$ & 2 \\
Anodic Inhibitor (phosphate) & DODICOR SA4 (30\%*) & $2.646^{* *}$ & 8 \\
Cathodic Inhibitor (zinc) & DODICOR SA10 (30\%*) & $7.716^{* *}$ & 3 \\
Inhibitor of Cu and its alloys (azole) & DODICOR SA20 (45\%*) & $9.080^{* *}$ & 1 \\
Biocide (chlorine) & NaClO $(10 \% *)$ & 0.73 & 0.5 \\
\hline
\end{tabular}

$(*)$ Data refers to the approximate value of the concentration of active ingredient in the chemical additives with similar formulations used in open recirculating cooling systems.

$\left.{ }^{* *}\right)$ Data refers to March, 2012 (Petrobras, 2015)

\subsubsection{Cooling tower fill}

Although the cooling tower of REGAP is counterflow, the Brentwood's V-Bar Crossflow Splash Fill was selected because of the available data of Brentwood's fills. They are of adequate height $(Z=10.97 \mathrm{~m})$ for the high recirculating water flow $\left(\dot{Q}_{w}=2300 \mathrm{~m}^{3} / \mathrm{h}\right)$, besides being recommended for situations that have high probability of fouling (Brentwood, 2015).

\subsubsection{Capital cost}

In this work, the capital cost was based on the cooling tower fill volume. The cost based on the tower fill volume $\left(C_{C T V}\right)$ is $2006.6 \mathrm{US} \$ / \mathrm{m}^{3}$, and the annualization factor is equal to 0.2983 year $^{-1}$ (Serna-González et al., 2010). Besides, the conversion rate is $0.38 \mathrm{US} \$ / \mathrm{R} \$$ (Banco Central, 2015).

\subsubsection{Pump}

This study selected a KSB Meganorm centrifugal pump, which can pump water and provide flow rates up to $3700 \mathrm{~m}^{3} / \mathrm{h}$. The KSB Meganorm
$350 / 370$ A centrifugal pump, selected for the recirculating water flow $\left(2300 \mathrm{~m}^{3} / \mathrm{h}\right)$, presents the head equal to $19 \mathrm{~m}$ and shaft power equal to 164.05 kW (KSB, 2015).

\subsubsection{Fan}

The fans move air through the tower. Equation 21 determines the fan power (Castro et al., 2000):

POW $_{f}=0.0548 \cdot \frac{\dot{m}_{\text {air }}}{\rho_{\text {air }}} 0.001$

\subsubsection{Water and electricity costs}

The water and electricity costs are necessary for the calculation of the make-up water cost and the electricity consumed by the pump and the fan.

The water cost coefficient for the make-up water scenarios $M 1, M 2, M 3$, and M4 was $R \$$ $1.00 / \mathrm{m}^{3}$, which represents the price of reuse water of the effluent of the refinery used in REGAP (Souza, 2015). The cost coefficient for M5 was R\$ $0.70 / \mathrm{m}^{3}$, which corresponds to the cost of the water obtained from the Ibirite Lagoon (Minas Gerais, Brazil) (Souza, 2015). The cost coefficient 
for $M 6$ was $R \$ 2.90 / \mathrm{m}^{3}$, which represents the cost of the reuse of the secondary effluent from the effluent treatment station at Rio de Janeiro's International Airport (ETE APOIO) by using reverse osmosis (Carvalho \& Machado, 2010).

Finally, the electricity cost coefficient was $\mathrm{R} \$$ $0.4038 / \mathrm{kWh}$, which corresponds to the electricity cost for the industry in Brazil (Firjan, 2015).

\subsection{0ptimization model}

In this study, the cost of the make-up water and the chemicals of the cooling tower was minimized for two cases, according to the Puckorius Index interval. Thus, case 1 considers $5.1 \leq \mathrm{PI} \leq 7.5$ and the use of chemical additives; case 2 considers $6.1 \leq \mathrm{PI} \leq 7$ and the absence of chemical additives.

The cycle of concentration is the decision variable of the optimization model. The operational range of the cycle of concentration is $1<C C \leq 16.5$, in which the minimum value represents the absence of water recirculation and the maximum value represents maximum water recirculation $\left(\dot{Q}_{b}=0\right)$. Besides, the maximum silica concentration in the recirculating water must be $180 \mathrm{ppm}$ (CC $\leq$ $\left.\frac{180}{c_{\mathrm{SiO}_{2} m}}\right)$.

The nonlinear model was implemented in the GAMS software, using the CONOPT 3 solver (Rosenthal, 2014). This solver is based on the Generalized Reduced Gradient (GRG) method. Although the optimization model is simple, GAMS facilitates the analysis of different case studies by being able to adapt quickly to new situations. Then, the optimization model can be written as:

\begin{tabular}{|l|}
\hline Minimize $C_{T O T}=C A P E X \cdot F+O P E X$ \\
\hline Subject to: \\
\hline CAPEX $=C_{C T V} \cdot A_{f r} \cdot Z$ \\
\hline OPEX $=H_{Y} \cdot C_{c m} \cdot \dot{Q}_{m}+H_{Y} \cdot C_{c e} \cdot\left(P O W_{p}\right.$ \\
$\left.\quad+P O W_{f}\right)+H_{Y}$ \\
$\quad \cdot\left(\dot{m}_{s o l} \cdot C_{c s}\right)$ \\
$\quad+\sum_{n}^{N T} D_{a, n} \cdot C_{c a, n}$ \\
$\quad+\sum_{n}^{N T} H_{Y} \cdot\left(C_{c a, n} \cdot \dot{m}_{a, n}\right)$ \\
\\
$\dot{Q}_{m}=\dot{Q}_{b}+\dot{Q}_{e}+\dot{Q}_{d}+\dot{Q}_{l}$ \\
\hline$\dot{Q}_{e}=0.00173 \cdot \dot{Q}_{w} \cdot\left(T_{w 1}-T_{w 2}\right)$ \\
\hline$\dot{Q}_{d}=0.001 \dot{Q}_{w}$ \\
\hline
\end{tabular}

\begin{tabular}{|c|c|}
\hline$C C=\frac{\left(\dot{Q}_{b}+\dot{Q}_{d}+\dot{Q}_{l}+\right.}{\left(\dot{Q}_{b}+\dot{Q}_{d}+\dot{Q}_{l}\right.}$ & \\
\hline$\dot{m}_{a, n}=\frac{c_{a, n} \cdot \dot{Q}_{m}}{(C C \cdot 1000)}$ & \\
\hline$P I=\left(2 \cdot p H_{s}\right)-p H_{e q}$ & \\
\hline$p H_{e q}=1.47 \cdot \log \left(c_{A T}\right.$ & -4.54 \\
\hline$p H_{s}=(9.3+A+B)-$ & $+D)$ \\
\hline$A=\frac{\log \left(c_{T D S C}\right)-1}{10}$ & 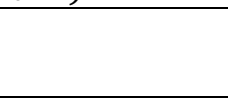 \\
\hline$B=-13.12 \cdot \log \left(T_{m}\right.$ & 73) +34.55 \\
\hline$C=\log \left(c_{C a^{2+}{ }_{c}}\right)-0.4$ & \\
\hline$D=\log \left(c_{A T C}\right)$ & \\
\hline$C C=\frac{C_{A T c}}{C_{A T_{m}}}$ & \\
\hline$C C=\frac{c_{T D S c}}{c_{T D S m}}$ & \\
\hline$C C=\frac{C_{C a^{2+} c}}{c_{C a^{2+} m}}$ & \\
\hline$C C \leq \frac{180}{C_{\mathrm{SiO}_{2} \mathrm{~m}}}$ & \\
\hline $1<C C \leq 16.5$ & \\
\hline$D_{a, n}=\frac{c_{a 0, n} \cdot V}{1000}$ & \\
\hline$\dot{m}_{s o l}=\frac{c_{c l} \cdot \dot{Q}_{w}}{\% p / p \cdot 1000}$ & \\
\hline Case 1 & Case 2 \\
\hline $\begin{array}{l}5.1 \leq P I \leq 7.5 \\
c_{a, d}=\frac{2}{0.4} \\
c_{a 0, d}=\frac{20}{0.4} \\
c_{a, c i}=\frac{8}{0.3} \\
c_{a 0, c i}=\frac{50}{0.3} \\
c_{a, a i}=\frac{3}{0.3} \\
c_{a 0, a i}=\frac{15}{0.3} \\
c_{a, c u i}=\frac{1}{0.45} \\
c_{a 0, c u i}=\frac{15}{0.45} \\
c_{c l}=0.5 \% p / p=0.1\end{array}$ & $\begin{array}{l}6.1 \leq P I \leq 7 \\
c_{a, n}=0 \\
c_{a 0, n}=0 \\
c_{c l}=0\end{array}$ \\
\hline
\end{tabular}

The values for the parameters considered in this work are shown in Table 5.

\section{RESULTS AND DISCUSSIONS}

The results of the optimization of a cooling tower of $10.97 \mathrm{~m}$ fill height and $4.27 \mathrm{~m}$ horizontal fill air travel are presented for the make-up water scenarios M1, M2, M3, M4, M5, and M6 (Tables 6 
Table 5. Data for the case study.

\begin{tabular}{|c|c|}
\hline Parameter & Value \\
\hline$F\left(\right.$ year $\left.^{-1}\right)$ & 0.2983 \\
\hline$C_{C T V}\left(\mathrm{R} \$ / \mathrm{m}^{3}\right)$ & 5280.53 \\
\hline$A_{f r}\left(\mathrm{~m}^{2}\right)$ & 18.2 \\
\hline $\boldsymbol{Z}(\mathrm{m})$ & 10.97 \\
\hline $\boldsymbol{H}_{\boldsymbol{Y}}(\mathrm{h} /$ year $)$ & 8000 \\
\hline $\boldsymbol{\rho}_{\text {air }}\left(\mathrm{kg} / \mathrm{m}^{3}\right)$ at $20^{\circ} \mathrm{C}$ & $1.2041^{*}$ \\
\hline $\boldsymbol{\rho}_{\mathbf{w}}\left(\mathrm{kg} / \mathrm{m}^{3}\right)$ at $37.5^{\circ} \mathrm{C}$ & $993 *$ \\
\hline $\mathbf{T}_{\mathrm{w} 1}(\mathrm{~K})$ & $307.15^{* *}$ \\
\hline $\mathbf{T}_{\mathrm{w} 2}(\mathrm{~K})$ & $298.15^{* *}$ \\
\hline$\dot{Q}_{w}\left(\mathrm{~m}^{3} / \mathrm{h}\right)$ & $2300 * *$ \\
\hline$\dot{Q}_{l}\left(\mathrm{~m}^{3} / \mathrm{h}\right)$ & $0.01^{* *}$ \\
\hline$V\left(m^{3}\right)$ & $903 * *$ \\
\hline$\dot{\boldsymbol{m}}_{w} / \dot{\boldsymbol{m}}_{\text {air }}$ & 0.56 \\
\hline $\boldsymbol{C}_{\boldsymbol{c m}}$ for $\mathrm{M} 1, \mathrm{M} 2, \mathrm{M} 3, \mathrm{M} 4\left(\mathrm{R} \$ / \mathrm{m}^{3}\right)$ & 1.00 \\
\hline $\boldsymbol{C}_{\boldsymbol{c m}}$ for M5 (R\$/m $\left.\mathrm{m}^{3}\right)$ & 0.70 \\
\hline$C_{c m}$ for M6 $\left(\mathrm{R} \$ / \mathrm{m}^{3}\right)$ & 2.90 \\
\hline$C_{c e}(\mathrm{R} \$ / \mathrm{kWh})$ & 0.4038 \\
\hline $\boldsymbol{P O W}_{p}(\mathrm{~kW})$ & 164.05 \\
\hline $\mathbf{P O W}_{\mathrm{f}}(\mathrm{kW})$ & 185.61 \\
\hline
\end{tabular}

and 7), considering the Puckorius Index intervals (Cases 1 and 2).

Figures 2, 3, 4, 5, 6, and 7 show the operational cost versus the cycle of concentration and the operational cost versus the Puckorius Index for $\mathrm{M} 1$, $\mathrm{M} 2, \mathrm{M} 3, \mathrm{M} 4, \mathrm{M} 5$, and M6, respectively.

Although the higher cycle of concentration permits the reduction of the make-up water and chemical flow rates, the results show that the total cost of case $1(5.1 \leq \mathrm{PI} \leq 7.5)$ for all make-up water scenarios is higher than the one of case 2 $(6.1 \leq \mathrm{PI} \leq 7)$. However, the use of chemical additives prolongs the lifespan of the cooling system and maintains the efficiency of the heat transfer process. Furthermore, the cost of additives of case 1 was lower than the capital cost, which reinforces the importance of their use in the process.

The power cost has a significant value and it was considered constant at all cycles of concentration. Nonetheless, the higher the cycle of concentration, the higher the salt concentration in the recirculating water, which is connected with the density and viscosity of the water. Thus, variations in pumping as a function of liquid properties like density and viscosity can change the results.

The Puckorius Index equal to 5.1 indicates a slight scale formation. Therefore, the use of inhibitors and dispersants is essential in case 1. Besides, the use of chemical additives is

Table 6. Optimization results for the make-up water scenarios $M 1, M 2, M 3$, and $M 4$.

\begin{tabular}{|c|c|c|c|c|c|c|c|c|}
\hline Variables & $\begin{array}{c}\text { M1 } \\
\text { Case } 1\end{array}$ & $\begin{array}{c}\text { M1 } \\
\text { Case } 2\end{array}$ & $\begin{array}{c}\text { M2 } \\
\text { Case } 1\end{array}$ & $\begin{array}{c}\text { M2 } \\
\text { Case } 2 \\
\end{array}$ & $\begin{array}{c}\text { M3 } \\
\text { Case } 1\end{array}$ & $\begin{array}{c}\text { M3 } \\
\text { Case } 2 \\
\end{array}$ & $\begin{array}{c}\text { M4 } \\
\text { Case } 1\end{array}$ & $\begin{array}{c}\text { M4 } \\
\text { Case } 2 \\
\end{array}$ \\
\hline $\begin{array}{l}\text { Puckorius } \\
\text { Index (PI) }\end{array}$ & 5.1 & 6.1 & 5.1 & 6.1 & 5.1 & 6.1 & 5.1 & 6.1 \\
\hline $\begin{array}{l}\text { Cycle of } \\
\text { concentration }\end{array}$ & 6.97 & 4.5 & 9.78 & 6.3 & 12.16 & 7.86 & 14.26 & 9.21 \\
\hline $\begin{array}{l}\text { Make-up flow } \\
\text { rate }\left(m^{3} \cdot h^{-1}\right)\end{array}$ & 41.81 & 46.04 & 39.89 & 42.55 & 39.02 & 41.03 & 38.51 & 40.17 \\
\hline $\begin{array}{l}\text { Capital Cost } \\
\left(\mathrm{R} \$ \text {. year }{ }^{-1}\right)\end{array}$ & 314,727 & 314,727 & 314,727 & 314,727 & 314,727 & 314,727 & 314,727 & 314,727 \\
\hline $\begin{array}{l}\text { Power Cost } \\
\left(\text { R\$ . year }{ }^{-1}\right) \\
\text { Make-up }\end{array}$ & $1,129,562$ & $1,129,562$ & $1,129,562$ & $1,129,562$ & $1,129,562$ & $1,129,562$ & $1,129,562$ & $1,129,562$ \\
\hline $\begin{array}{l}\text { water cost } \\
\left(\mathrm{R} \$ \text {. year }{ }^{-1}\right) \\
\text { Chemicals }\end{array}$ & 334,499 & 368,321 & 319,122 & 340,366 & 312,163 & 328,283 & 308,092 & 321,371 \\
\hline $\begin{array}{l}\text { cost } \\
\left(\mathrm{R} \$ \text {. } \text { year }^{-1}\right)\end{array}$ & 80,278 & 0 & 76,608 & 0 & 74,947 & 0 & 73,975 & 0 \\
\hline $\begin{array}{l}\text { Total cost } \\
\left(\mathrm{R} \$ \text {. year }{ }^{-1}\right)\end{array}$ & $1,859,067$ & $1,812,609$ & $1,840,019$ & $1,784,655$ & 1,831,399 & $1,772,573$ & $1,826,356$ & $1,765,660$ \\
\hline
\end{tabular}


Table 7. Optimization results for the make-up water scenarios M5 and M6.

\begin{tabular}{|c|c|c|c|c|}
\hline Variables & $\begin{array}{c}\text { M5 } \\
\text { Case } 1\end{array}$ & $\begin{array}{c}\text { M5 } \\
\text { Case } 2\end{array}$ & $\begin{array}{c}\text { M6 } \\
\text { Case } 1\end{array}$ & $\begin{array}{c}\text { M6 } \\
\text { Case } 2\end{array}$ \\
\hline Puckorius Index (PI) & 5.1 & 6.1 & 5.2 & 6.1 \\
\hline Cycle of concentration & 5.50 & 3.56 & 8.57 & 5.77 \\
\hline Make-up flow rate $\left(\mathrm{m}^{3} \cdot \mathrm{h}^{-1}\right)$ & 43.76 & 49.83 & 40.54 & 43.32 \\
\hline $\begin{array}{l}\text { Capital Cost } \\
\left(\mathbf{R} \$ \cdot \text { year }^{-1}\right)\end{array}$ & 314,727 & 314,727 & 314,727 & 314,727 \\
\hline $\begin{array}{l}\text { Power Cost } \\
\left(\mathrm{R} \$ \text {. } \text { year }^{-1}\right)\end{array}$ & $1,129,562$ & $1,129,562$ & $1,129,562$ & $1,129,562$ \\
\hline Make-up water cost (R\$ . year $\left.{ }^{-1}\right)$ & 245,077 & 279,030 & 940,546 & $1,004,949$ \\
\hline $\begin{array}{l}\text { Chemical costs } \\
\left(\mathrm{R} \$ \cdot \text { year }^{-1}\right)\end{array}$ & 84,004 & 0 & 77,850 & 0 \\
\hline $\begin{array}{l}\text { Total cost } \\
\left(\mathbf{R} \$ \cdot \text { year }^{-1}\right)\end{array}$ & $1,773,370$ & $1,723,319$ & $2,462,685$ & $2,449,238$ \\
\hline
\end{tabular}

advantageous because it permits the elevation of the cycle of concentration and, consequently, the reduction of the make-up water cost.

The optimal cycle of concentration of M4 in case 1 ( $C C=14.26)$ was very close to the maximum cycle of concentration (16.5). Thus, among the possible kinds of make-up water of the cooling tower of REGAP studied by Veiga (2010), M4 presented the optimal cycle of concentration, having the lowest total cost.

Although the optimal cycles of concentration of M5 in cases 1 and 2 were lower than the ones obtained for $M 1, M 2, M 3$, and $M 4$, the make-up water cost of M5 was lower because of its lower cost coefficient $\left(\mathrm{R} \$ 0.70 / \mathrm{m}^{3}\right)$. Therefore, the total cost was also lower than the cost of the possible kinds of make-up water in the cooling tower of the Coking Unit of REGAP.

Different from the other scenarios, the Puckorius index of $\mathrm{M} 6$ in case 1 ( $\mathrm{PI}=5.2)$ was not the minimum because of the maximum allowed concentration of silica. The make-up water cost of M6 was high because of the high cost coefficient for this kind of water (R\$ $\left.2.90 / \mathrm{m}^{3}\right)$. Consequently, M6 presented the highest total cost studied in this work.

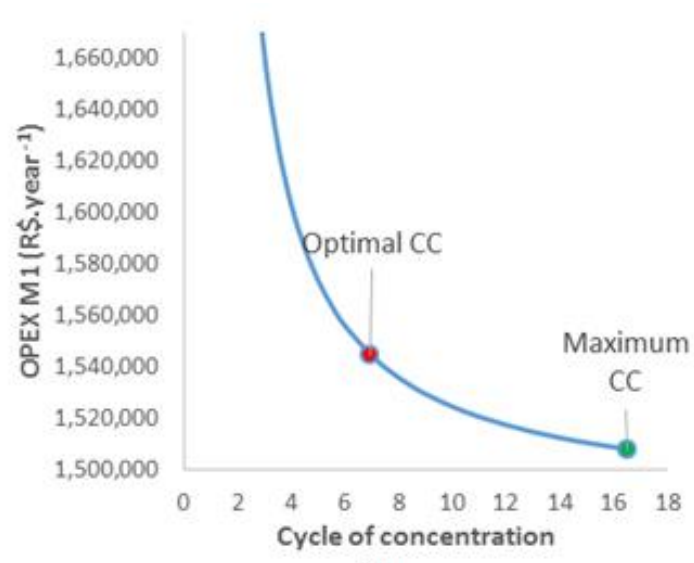

(a)

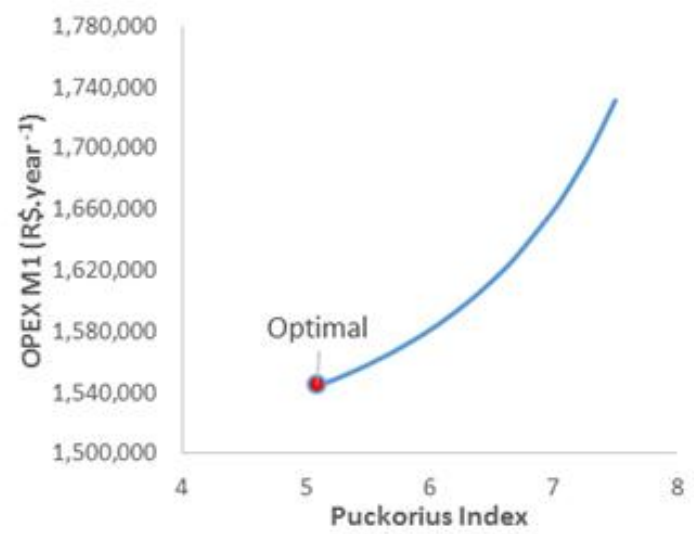

(b)

Figure 2. Operational cost versus the cycle of concentration (a) and the operational cost versus the Puckorius Index (b) for the make-up water scenario M1. 


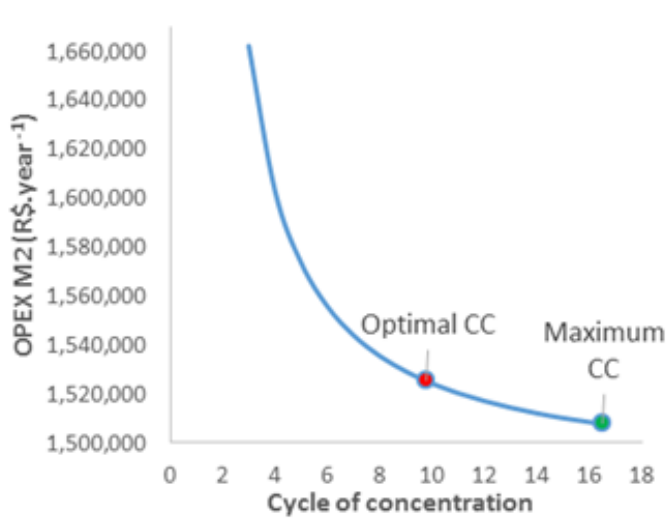

(a)

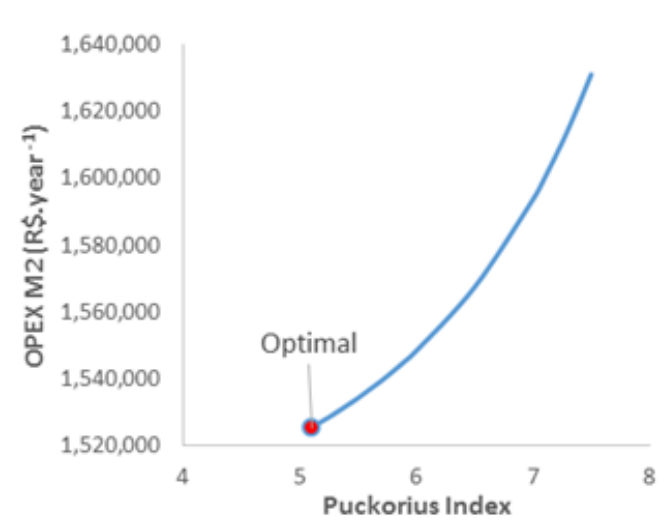

(b)

Figure 3. Operational cost versus the cycle of concentration (a) and the operational cost versus the Puckorius Index (b) for the make-up water scenario M2.

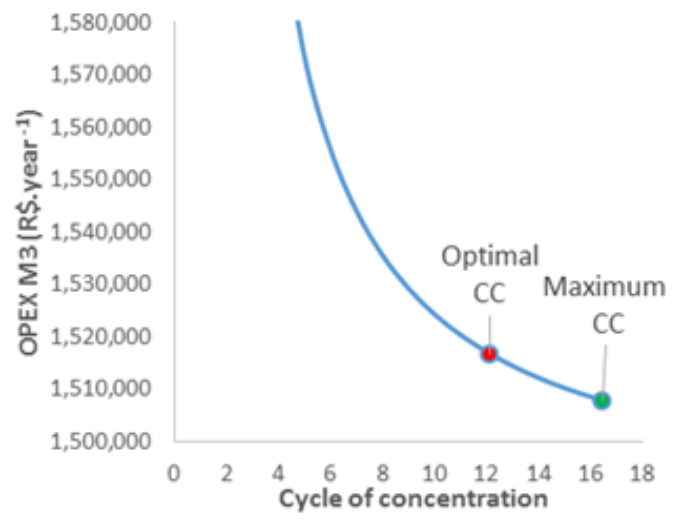

(a)

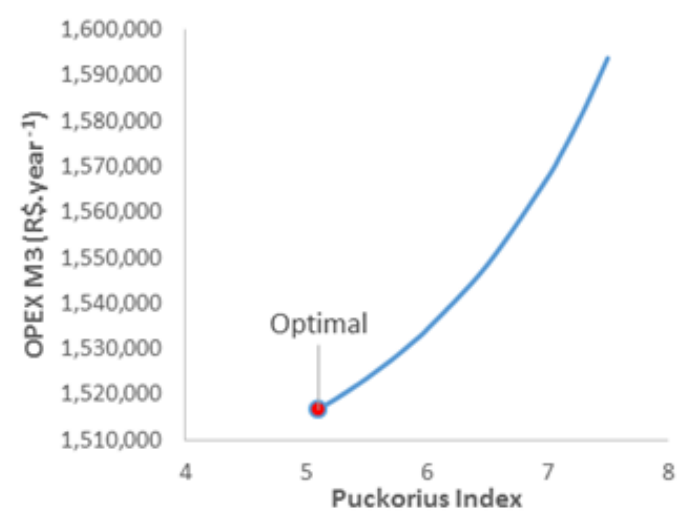

(b)

Figure 4. Operational cost versus the cycle of concentration (a) and the operational cost versus the Puckorius Index (b) for the make-up water scenario M3.

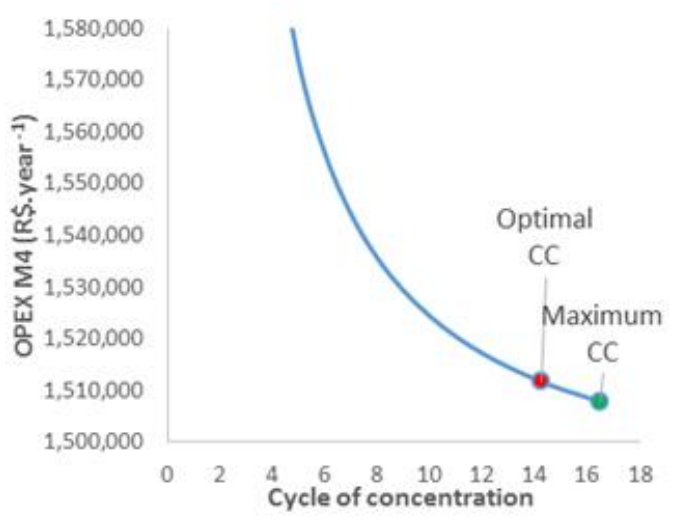

(a)

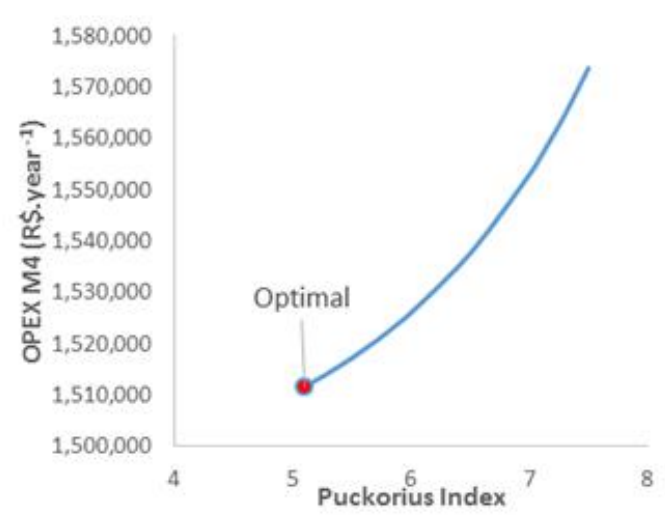

(b)

Figure 5. Operational cost versus the cycle of concentration (a) and the operational cost versus the Puckorius Index (b) for the make-up water scenario M4. 


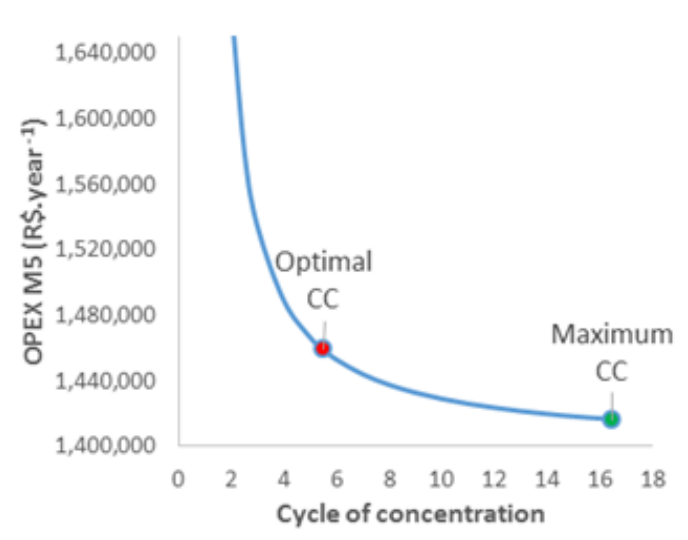

(a)

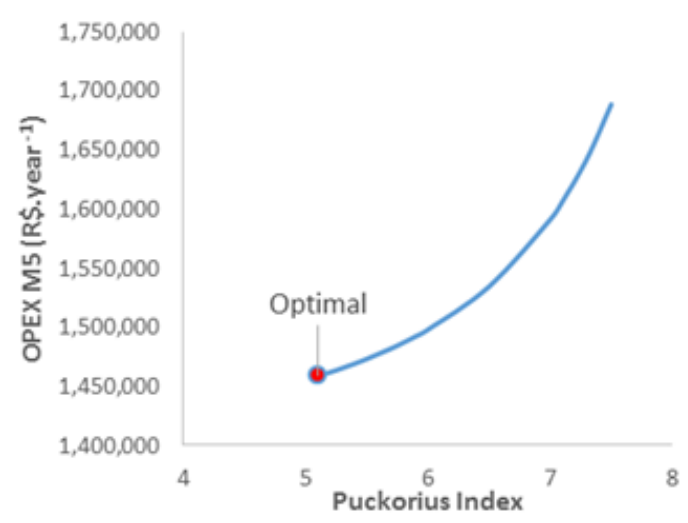

(b)

Figure 6. Operational cost versus the cycle of concentration (a) and the operational cost versus the Puckorius Index (b) for the make-up water scenario M5.

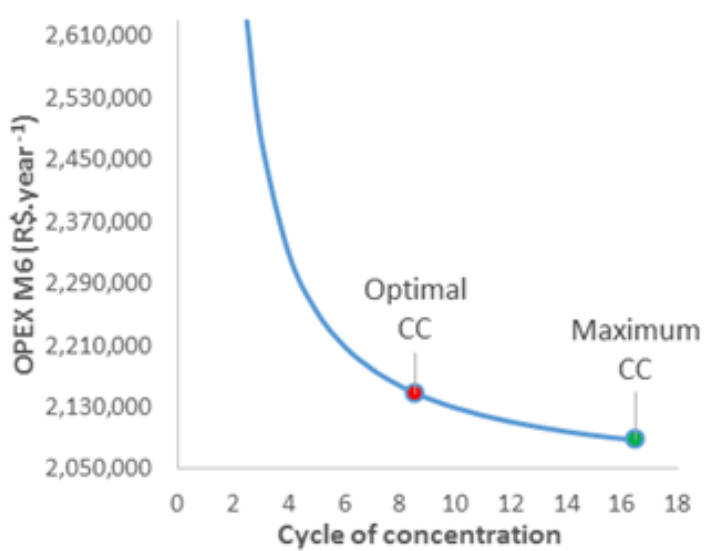

(a)

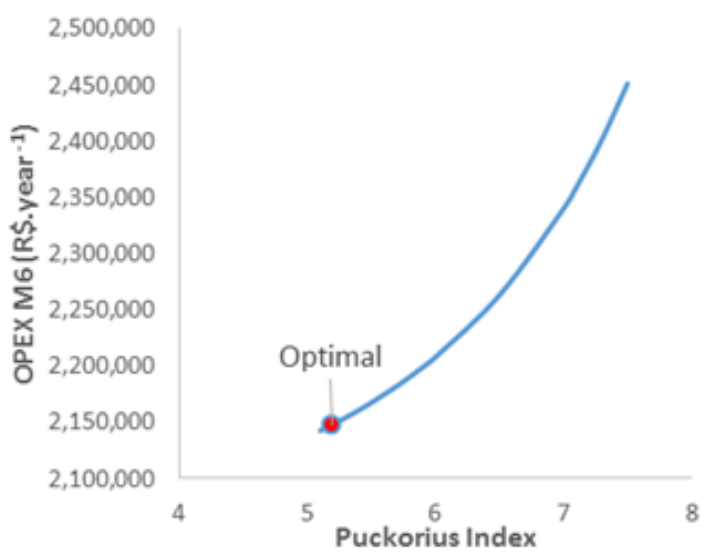

(b)

Figure 7. Operational cost versus the cycle of concentration (a) and the operational cost versus the Puckorius Index (b) for the make-up water scenario M6.

The results showed that the minimum cost is obtained with the higher cycle of concentration that is allowed according to the Puckorius Index interval and the maximum allowed concentration of silica.

\section{CONCLUSIONS}

As one of the main purposes of water in oil refineries is cooling the processes or equipment, models that minimize the costs associated with cooling towers are advantageous.
From the optimization model and the operational data of the cooling tower of REGAP, some case studies were performed with different compositions of make-up water, to minimize the make-up water and chemical additives costs. The results showed that the minimum cost is obtained with the highest allowed cycle of concentration according to the Puckorius Scaling Index interval. Although all scenarios presented the lowest total cost in the cases that did not include the use of chemical additives, the presence of dispersant, inhibitors, and biocides prolong the lifespan of the cooling system and maintains the operational efficiency. Furthermore, the presence of chemical 
additives allows a higher cycle of concentration and, consequently, the minimization of the makeup water and chemical costs, besides reducing the negative environmental impacts associated with the blowdown.

\section{ACKNOWLEDGEMENTS}

The authors greatly acknowledge Mr. Paul Tasca, a Brentwood employee, for allowing Sanches, H. L. to access part of Brentwood's site, and Andrea Veiga, a Petrobras employee, for providing the necessary data.

\section{NOMENCLATURE}

\section{Greek Letters}

$\lambda$ Water latent heat of evaporation $(\mathrm{kJ} / \mathrm{kg})$

$\rho_{\mathrm{w}}$ Water density $\left(\mathrm{kg} / \mathrm{m}^{3}\right)$

$\rho_{\text {air }}$ Air density $\left(\mathrm{kg} / \mathrm{m}^{3}\right)$

\section{Symbols}

$\% p / p$ Weight percent of active chlorine in the chemical additive (\%)

$A$ Coefficient based on the TDS

$A_{f r}$ Cross-sectional area of the cooling tower $\left(\mathrm{m}^{2}\right)$

$B$ Coefficient based on temperature

$C$ Coefficient based on calcium hardness

$c_{a}$ Chemical additive concentration in the recirculating water $(\mathrm{mg} / \mathrm{L})$

$c_{a, a i}$ Anodic inhibitor concentration in the recirculating water $(\mathrm{mg} / \mathrm{L})$

$c_{a, c i}$ Cathodic inhibitor concentration in the recirculating water $(\mathrm{mg} / \mathrm{L})$

$c_{a, c u i}$ Inhibitor of $\mathrm{Cu}$ and its alloys concentration in the recirculating water $(\mathrm{mg} / \mathrm{L})$

$c_{a, d}$ Dispersant concentration in the recirculating water ( $\mathrm{mg} / \mathrm{L})$

$c_{a, n}$ Concentration of the chemical additive $\mathrm{n}$ in the recirculating water $(\mathrm{mg} / \mathrm{L})$

$c_{a 0}$ Initial concentration of the chemical additive in the recirculating water $(\mathrm{mg} / \mathrm{L})$

$c_{a 0, n}$ Initial concentration of the chemical additive $\mathrm{n}$ in the recirculating water $(\mathrm{mg} / \mathrm{L})$

Capex Capital cost of the cooling tower ( $\mathrm{R} \$ /$ year)
$c_{A T ~ c}$ Total alkalinity in the recirculating water (mg/L)

$c_{A T_{m}}$ Total alkalinity in the make-up water $(\mathrm{mg} / \mathrm{L})$

CC Cycle of concentration

$c_{c l}$ Concentration of chlorine in the recirculating water ( $\mathrm{mg} / \mathrm{L})$

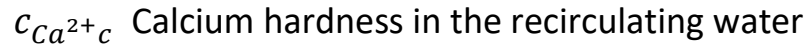
(mg/L)

${ }^{C_{C a}{ }^{2+}{ }_{m}}$ Calcium hardness in the make-up water (mg/L)

$C_{c a, n}$ Cost coefficient of the chemical additive $\mathrm{n}$ ( $\mathrm{R} \$ / \mathrm{kg})$

$C_{c e}$ Electricity cost coefficient ( $\left.\mathrm{R} \$ / \mathrm{kWh}\right)$

$C_{c m}$ Make-up water cost coefficient $\left(\mathrm{R} \$ / \mathrm{m}^{3}\right)$

$C_{c S}$ Cost coefficient of chlorine solution (sodium hypochlorite) (R\$/kg)

$\mathrm{CC}_{\max }$ Maximum cycle of concentration

$C_{C T V}$ Cooling tower cost based on fill volume $\left(\mathrm{R} \$ / \mathrm{m}^{3}\right)$

$c_{m}$ Salt concentration in the make-up water $(\mathrm{mg} / \mathrm{L})$

$c_{p w}$ Water specific heat $\left(\mathrm{kJ} /\left(\mathrm{kg} .{ }^{\circ} \mathrm{C}\right)\right)$

$c_{S}$ Salt concentration in the recirculating water (mg/L)

$c_{\mathrm{SiO}_{2} m}$ Silica concentration in the make-up water (mg/L)

$c_{T D S}$ c Total dissolved solids in the recirculating water $(\mathrm{mg} / \mathrm{L})$

$c_{T D S} m$ Total dissolved solids in the make-up water ( $\mathrm{mg} / \mathrm{L})$

$C_{T O T}$ Total cost of the cooling tower ( $\mathrm{R} \$ /$ year)

$D$ Coefficient based on total alkalinity

$D_{a}$ Slug dose of the chemical additive $(\mathrm{kg})$

$D_{a, n}$ Slug dose of the chemical additive $\mathrm{n}(\mathrm{kg})$

$F$ Annualization fator $\left(\right.$ year $^{-1}$ )

$H_{Y}$ Yearly operating time (h/year)

$\dot{m}_{\text {air }}$ Air mass flow rate $(\mathrm{kg} / \mathrm{h})$

$\dot{m}_{a, n}$ Continuous dose of the chemical additive $\mathrm{n}$

(kg/h)

$\dot{m}_{\text {sol }}$ Dosage of sodium hypochlorite solution

$(\mathrm{kg} / \mathrm{h})$

$\dot{m}_{w}$ Recirculating water mass flow rate $(\mathrm{kg} / \mathrm{s})$

$n$ Chemical additive

NT Total number of chemical additives used in the cooling tower except chlorine

Opex Operational cost of the cooling tower (R\$/year) 
$p H_{e q}$ Equilibrium $\mathrm{pH}$

$p H_{s}$ Saturation $\mathrm{pH}$

PI Puckorius Scaling Index

$P O W_{f}$ Fan power (kW)

$P O W_{p}$ Pump power (kW)

$\dot{Q}_{b}$ Blowdown water flow rate $\left(\mathrm{m}^{3} / \mathrm{h}\right)$

$\dot{Q}_{d}$ Water flow rate lost by $\mathrm{drift}\left(\mathrm{m}^{3} / \mathrm{h}\right)$

$\dot{Q}_{e}$ Water flow rate lost by evaporation $\left(\mathrm{m}^{3} / \mathrm{h}\right)$

$\dot{Q}_{l}$ Water flow rate lost by possible leaks $\left(\mathrm{m}^{3} / \mathrm{h}\right)$

$\dot{Q}_{m}$ Make-up water flow rate $\left(\mathrm{m}^{3} / \mathrm{h}\right)$

$\dot{Q}_{w}$ Recirculating water flow rate $\left(\mathrm{m}^{3} / \mathrm{h}\right)$

TTA Tolyltriazole

$T_{m}$ Make-up water temperature (K)

$T_{w 1}$ Inlet water temperature (K)

$T_{w 2}$ Outlet water temperature (K)

$V$ Volume of water in the cooling system $\left(\mathrm{m}^{3}\right)$

$Z$ Fill height $(\mathrm{m})$

\section{REFERENCES}

Banco Central. Conversão de moedas. Available at: <http://www4.bcb.gov.br/pec/conversao/ conversao.asp $>$. Accessed on: February 2015. (in Portuguese).

Basham, D.L.; Wright, J.W.; Ferguson, K.I.; Moy, G.W. Industrial water treatment operation and maintenance. Unified Facilities Criteria (UFC), UFC 3-240-13FN, Department of Defense, USA, 2005.

Brentwood. Brentwood Cooling Tower. Available <http://www.brentwoodindustries.com/>. Accessed on: August 2015.

Carrier (Carrier Air Conditioning Company). Handbook of Air Conditioning System Design. New York: McGraw-Hill Books, 1965.

Carvalho, D. D.; Machado, B. J. F. Reuso de efluentes em torres de resfriamento- estudo conceitual: Aeroporto Internacional do Rio de Janeiro. Acta Scientiarum, v.32, p. 295-302, 2010. (in Portuguese).

https://doi.org/10.4025/actascitechnol.v32i3.865
Castro M. M.; Song T.W.; Pinto J.M. Minimization of operational cost in cooling water systems. Trans IChemE, v.78, p. 192-201, 2000. https://doi.org/10.1205/026387600527220

Cheremisinoff, N.P.; Cheremisinoff, P.N. Cooling Towers: Selection, Design and Practice. Ann Arbor Science, Ann Arbor, Michigan, 1981.

Cortinovis, G. F.; Paiva, J. L.; Song, T. W.; Pinto, J.M. A systemic approach for optimal cooling tower operation. Energy Conversion and Management, v.50, p. 2200-2209, 2009.

https://doi.org/10.1016/j.enconman.2009.04.033

FEMP (Federal Energy Management Program). Cooling towers: understanding key components of cooling towers and how to improve water efficiency. 2011. Available at: < http://www1.eere.energy.gov/femp/pdfs/waterfs_ coolingtowers.pdf>. Accessed on: December 2013.

FIRJAN. Quanto custa a energia elétrica para a indústria no Brasil? Available at: <http://www.quantocustaenergia.com.br>. Accessed on: February 2015. (in Portuguese).

GE (General Electric Company). Handbook of Industrial Water treatment. Available at: <https://www.gewater.com/handbook/cooling_wa ter_systems/ch_27_chlorine.jsp>. Accessed on: January 2017.

Gentil, V. Corrosão. 3ạed. Rio de Janeiro: Editora LTC- Livros Técnicos e Científicos, 2003. (in Portuguese).

Kim, K., SAVULESCU, L. and SMITH, R. Design of cooling systems for effluent temperature reduction. Chemical Engineering Science, v. 56, p. 1811-1830, 2001. https://doi.org/10.1016/S00092509(00)00541-8

KSB. Manual de serviço KSB Meganorm. Available at: <http://www.ksb.com.br>. Accessed on: May 2015. (in Portuguese).

Mirre, R. C. Metodologia para o gerenciamento sustentável do reúso de águas e efluentes industriais por meio da integração de processos. Tese de doutorado. Programa de Pós-graduação em Tecnologia de Processos Químicos e Bioquímicos, Universidade Federal do Rio de Janeiro, 2012. (in Portuguese). 
OMNI. Torres de resfriamento de água. Available at: <http://www.omnigrupo. com.br/pdf/apostila_omni.pdf>. Accessed on: December 2013. (in Portuguese)

Pereira, C. A. Tratamentos físico-químicos de água. Volume 1. Rio de Janeiro: Apostila do curso de Engenharia de Produção, Universidade do Estado do Rio de Janeiro, Campus Regional de Resende, 2001. (in Portuguese).

Perry, R. H.; Green, D. W. Perry's Chemical Engineers' Handbook. $8^{\text {th }}$ ed. New York: McGraw Hill, 2008.

Petrobras. Portal de Transparência da Petrobras. Available at: <http://sites.petrobras.com.br/minisite/acessoainf ormacao/materiaishtm/contratos_materiais/PORT AL_1000_M/Documents/Mar2012.htm>. Accessed on: February 2015. (in Portuguese).

Rajagopal, S.; Jenner, H.A.; Venugopalan, V.P. Operational and Environmental Consequences of Large Industrial Cooling Water Systems. New York: Springer, 2012. https://doi.org/10.1007/978-1-46141698-2

Roberge, P. R. Corrosion Inspection and Monitoring. New York: Wiley, 2007. 383p. https://doi.org/10.1002/0470099763

Rosenthal, R. E. GAMS- A user's guide. Washington, D.C: GAMS Development Corporation, 2014.
Santos, L. M. M. Índice de qualidade de água subterrânea aplicado em área de aquíferos cristalinos com uso agrícola: Bacia do rio São Domingos-RJ. Tese de doutorado. Programa de Pós-Graduação em Geologia, Universidade Federal do Rio de janeiro, 2009. (in Portuguese).

Serna-González, M.; Ponce-Ortega, J.M.; Jiménez-Gutiérrez, A. MINLP optimization of mechanical draft counter flow wet-cooling towers. Chemical Engineering Research and Design, v. 88, p. 614-625, 2010. https://doi.org/10.1016/j.cherd.2009.09.016

Souza, K. R. Otimização da operação de torres de resfriamento. In: I Congresso Brasileiro de Gestão Ambiental - IBEAS, 2010, Bauru, São Paulo. (in Portuguese).

Souza, R. S. Reúso de água em sistema de resfriamento com eletrodiálise reversa. In: 20 Simpósio Internacional de reúso de água - ABES, 2015, Curitiba, Paraná. (in Portuguese).

Veiga, A. A. Estudo do efeito biocida do cloro e do peróxido de hidrogênio em sistemas de resfriamento com reúso de efluente como água de reposição. Tese de doutorado. Programa de Pósgraduação em Tecnologia de Processos Químicos e Bioquímicos, Universidade Federal do Rio de Janeiro, 2010. (in Portuguese). 